\title{
HUBUNGAN ANTARA KARAKTERISTIK ORANG TUA DENGAN STRES PENGASUHAN PADA ORANG TUA ANAK GANGGUAN SPEKTRUM AUTISME
}

\author{
Faizah Attamimi Nuha ${ }^{1}$, Asri Mutiara Putri², Nia Triswanti ${ }^{3}$ \\ 1Program Studi Kedokteran, Fakultas Kedokteran, Universitas Malahayati, email: \\ attamiminuha@gmail.com \\ 2Program Studi Psikologi, Fakultas Kedokteran, Universitas Malahayati, email: asri@malahayati.ac.id \\ 3Program Studi Kedokteran, Fakultas Kedokteran, Universitas Malahayati, email: \\ dr.niatriswanti82@gmail.com
}

\section{ABSTRACT: RELATIONSHIP BETWEEN PARENTAL CHARACTERISTICS AND PARENTING STRESS IN PARENTS OF CHILDREN WITH AUTISM SPECTRUM DISORDER}

Autism is a complex developmental disorder, includes disorders of communication, behavior, social skills, sensory and learning caused by brain damage. The level of parenting stress experienced by parents of autistic children is very high. Parental characteristics are one of the factors that influence parenting stress. This study aims to determine the relationship between parental characteristics and parenting stress of parents who have children with autism spectrum disorders. This research is an analytic survey research with a cross-sectional design. The research sample consisted of 31 parents who had children with autism spectrum disorders in special schools in Bandar Lampung. The measuring instruments used are parental demographic data and Parenting Stress Index (PSI). The results showed that most of the respondents were middle adults $(61.3 \%)$, tertiary education $(64.5 \%)$, working status $(54.8 \%)$, had an income more than Rp. 3,500,000 (74.2\%) and had moderat level of parenting stress $(74.2 \%)$. The results of the correlation analysis showed that there was a significant relationship between parental characteristics and parenting stress. Age and education are the strongest factors that predict parenting stress.

\section{Keyword: Parenting Stress, Parental Characteristics, Autism}

Autisme merupakan gangguan perkembangan yang kompleks seperti gangguan komunikasi, perilaku, kemampuan sosialisasi, sensoris dan belajar yang disebabkan oleh kerusakan otak. Tingkat stres pengasuhan yang dialami orang tua anak autis sangat tinggi. Karakteristik orang tua merupakan salah satu faktor yang mempengaruhi stres pengasuhan. Penelitian ini bertujuan untuk mengetahui hubungan karakteristik orang tua dengan stres pengasuhan orang tua yang memiliki anak gangguan spektrum autisme. Penelitian ini merupakan penelitian survei analitik dengan desain cross-sectional. Sampel penelitian berjumlah 31 orang tua yang memiliki anak ganggan spektrum autisme di SLB se-Bandar Lampung. Alat ukur yang digunakan adalah data demografi orang tua dan Parenting Stres Index (PSI). Hasil penelitian menunjukkan sebagian besar responden berusia dewasa madya $(61,3 \%)$, berpendidikan perguruan tinggi $(64,5 \%)$, status bekerja $(54,8 \%)$, memilikipendapatan > Rp.3.500.000 (74,2\%) dan memiliki tingkat stres pengasuhan sedang $(74,2 \%)$. Hasil analisis korelasi didapatkan adanya hubungan yang signifikan antara karakteristik orang tua dengan stres pengasuhan. Usia dan pendidikan menjadi faktor yang paling kuat memprediksi stress pengasuhan.

\section{Kata Kunci: Stres Pengasuhan, Karakteristik Orang Tua, Autisme}

\section{PENDAHULUAN}

Gangguan autisme merupakan

gangguan perkembangan yang kompleks

seperti gangguan perkembangan komunikasi, perilaku, kemampuan sosialisasi, sensoris, dan belajar disebabkan oleh adanya kerusakan otak. Gejala autisme biasanya mulai nampak pada anak berusia dibawah 3 tahun (Soendari, 2016). 
Jurnal Psikologi Malahayati, Volume 2, No.2, September 2020: 36-47

\section{HUBUNGAN ANTARA KARAKTERISTIK ORANG TUA DENGAN STRES PENGASUHAN PADA ORANG TUA ANAK GANGGUAN SPEKTRUM AUTISME}

Gangguan autisme semakin bertambah dari waktu ke waktu baik di dunia maupun di Indonesia. Pada tahun 2011, data dari United Nations Education Scientific and Cultural Organization (UNESCO) terdapat 35 juta orang penyandang autisme di dunia. Pada tahun 2013 dari data World Health Organization (WHO) prevalensi autisme di Indonesia terjadi peningkatan yang tinggi dibandingkan 10 tahun yang lalu, yaitu dari 1 per 1000 penduduk menjadi 8 per 1000 penduduk. Angka ini bahkan melampaui rata-rata dunia yaitu 6 per 1000 penduduk. Pada tahun 2015 diperkirakan terdapat 134.000 penyandang autisme di Indonesia (Judarwanto, 2015). Gangguan spektrum autisme dapat terjadi pada semua kelompok masyarakat kaya, miskin, di desa, di kota, berpendidikan, maupun tidak, serta semua kelompok etnis dan budaya di dunia (Suryati \& Rahawati, 2017). Hal ini menunjukkan bahwa autisme menjadi masalah besar bagi dunia sehingga perlu ditangani agar dapat mengurangi angka kejadian tersebut.

Menurut Suryati \& Rahmwati (2017) memiliki anak autisme masih menjadi mimpi buruk bagi sebagian besar orang tua dan beberapa orang tua langsung stres saat mendengar anaknya terdiagnosis autisme (dalam Putri, 2019). Tidak mudah bagi orang tua yang memiliki anak gangguan spektrum autisme untuk mengalami fase ini, sebelum akhirnya sampai pada tahap penerimaan (acceptance). Menurut Safaria (dalam Pamungkas, 2015) tidak sedikit orang tua yang kemudian memilih tidak terbuka mengenai keadaan anaknya kepada teman, tetangga bahkan keluarga dekat sekalipun, kecuali pada dokter yang menangani anaknya tersebut.

Menurut Osborne (dalam Fido \& Al-Saad, 2013) tingkat stres yang dialami oleh orang tua dari anak-anak dengan sindrom autisme sangat tinggi, dibandingkan dengan yang dialami oleh orang tua dari anak-anak yang mengalami hampir semua jenis gangguan ataupun masalah kesehatan. Penelitian Phelps, McCammon, Wuensch \& Golden (2009) membuktikan bahwa orang tua yang memiliki anak cacat atau gangguan diantaranya down syndrome, tourette syndrome, autisme dan $A D H D$, mengungkapkan bahwa yang memiliki tingkat stres pengasuhan tertinggi adalah orang tua dari anak dengan gangguan autisme.

Sikap orang tua yang mengalami stres akan memperparah keadaaan anak yang memiliki gangguan autisme. Hal ini akan berakibat buruk dalam pengasuhan karena stres yang dialami seringkali membuat ibu berperilaku tidak sehat dan tidak positif seperti menelantarkan anaknya bahkan berlaku kasar terhadap anaknya. Stres pengasuhan juga akan menghambat pekerjaan sehari-hari bahkan menghambat pertumbuhan anak dalam

Faizah Attamimi Nuha, Program Studi Kedokteran Fakultas Kedokteran Universitas Malahayati. Email: attamiminuha@gmail.com

Asri Mutiara Putri, Program Studi Psikologi Fakultas Kedokteran Universitas Malahayati. Email: asri@malahayati.ac.id

Nia Triswanti, Program Studi Kedokteran Fakultas Kedokteran Universitas Malahayati. Email: dr.niatriswanti82@gmail.com 
Jurnal Psikologi Malahayati, Volume 2, No.2, September 2020: 36-47

\section{HUBUNGAN ANTARA KARAKTERISTIK ORANG TUA DENGAN STRES PENGASUHAN PADA ORANG TUA ANAK GANGGUAN SPEKTRUM AUTISME}

kehidupannya. Akibatnya, orang tua hanya berdiam diri dan kondisi keterbelakangan anak semakin parah. Menurut Davis \& Carter (dalam Pamungkas, 2015) orang tua khususnya ibu harus mampu mengatasi stres dan segera bangkit untuk melakukan yang terbaik bagi anak.

Untuk mengurangi kecemasan dalam pengasuhan, maka orang tua harus mengetahui faktor-faktor yang mempengaruhi parenting stress. Faktor-faktor yang mempengaruhi pengasuhan menurut Wong (dalam Chairini, 2013) antara lain usia orang tua, keterlibatan orang tua, pendidikan orang tua, pengalaman sebelumnya dalam mengasuh anak, stres orang tua serta hubungan suami istri. Selain itu, tingkat pendapatan orang tua memiliki pengaruh terhadap tingkat stres pengasuhan yang dimiliki orang tua (Gupta, 2012). Hal ini diperkuat oleh hasil penelitian dari Nurul Charini (2013) bahwasannya terdapat hubungan yang bermakna antara pendapatan dengan stres pengasuhan, yaitu semakin rendah pendapatan keluarga perbulan semakin tinggi stres pengasuhan yang dialami. Berdasarkan latar belakang diatas, penelitian ini ingin menggali adakah hubungan karakteristik orang tua (usia, pendidikan, pekerjaan dan pendapatan) dengan stres pengasuhan orang tua?, adakah pengaruh karakteristik orang tua terhadap stres pengasuhan orang tua? dan apakah faktor- faktor yang paling dominan mempengaruhi stres pengasuhan orang tua yang memiliki anak gangguan spektrum autisme?

\section{METODE}

Penelitian ini menggunakan metode survey analitik dengan desain penelitian crosssectional. Penelitian ini dilaksanakan pada bulan Februari - Maret 2020. dan dilakukan di 3 SLB se-Kota Bandar Lampung yaitu SLB Yamet School, SLB Islam Terpadu Baitul Jannah dan SLB Dharma Bakti Dharma Pertiwi. Teknik sampling yang digunakan pada penelitian ini adalah Total Sampling. Jumlah sampel yang didapatkan sebanyak 31 orang tua yang memiliki anak gangguan spektrum autisme. Pengambilan data dilakukan dengan menyebarkan kuesioner demografi (usia, pendidikan, pekerjaan dan pendapatan orang tua) dan kuesioner pengukuran Parenting Stress Index (PSI).

Stres pengasuhan orang tua diukur menggunakan Parenting Stress Index-Short Form (PSI-SF) yang dikembangkan oleh Abidin (1994) memiliki 3 aspek yaitu: the parent distress, the difficult child, dan the parent-child dysfunctional interaction. Kuesioner stres pengasuhan terdiri dari 29 item pertanyaan. Kuesioner telah terbukti valid $(r=>.361)$ dan reliable $(\alpha=.915)$. Data dianalisis menggunakan

Faizah Attamimi Nuha, Program Studi Kedokteran Fakultas Kedokteran Universitas Malahayati. Email: attamiminuha@gmail.com

Asri Mutiara Putri, Program Studi Psikologi Fakultas Kedokteran Universitas Malahayati. Email: asri@malahayati.ac.id

Nia Triswanti, Program Studi Kedokteran Fakultas Kedokteran Universitas Malahayati. Email: dr.niatriswanti82@gmail.com 


\section{HUBUNGAN ANTARA KARAKTERISTIK ORANG TUA DENGAN STRES PENGASUHAN PADA ORANG TUA ANAK GANGGUAN SPEKTRUM AUTISME}

multiple regression dengan bantuan SPSS versi

24.

\section{HASIL}

Tabel 1

Distribusi Frekuensi Karakteristik Orang Tua

\begin{tabular}{lcc}
\hline \multicolumn{1}{c}{ Kategori } & F & $\%$ \\
\hline Usia & & \\
18 - 40 tahun & 12 & 38.7 \\
41 - 60 tahun & 19 & 61.3 \\
\hline Pendidikan & & \\
SD - SMP & 4 & 12.9 \\
SMA & 7 & 22.6 \\
Perguruan Tinggi & 20 & 64.5 \\
\hline Status Pekerjaan & & \\
$\quad$ Tidak Berkerja & 14 & 45.2 \\
Bekerja & 17 & 54.8 \\
\hline Pendapatan & & \\
< Rp. 1.500.000 & 1 & 3.2 \\
Rp. 1.500.000 - Rp. 2.500.000 & 3 & 9.7 \\
Rp. 2.500.000 - Rp. 3.500.000 & 4 & 12.9 \\
> Rp. 3.500.000 & 23 & 74.2 \\
Stres Pengasuhan & & 19.4 \\
Rendah & 6 & 74.2 \\
Sedang & 23 & 6.5 \\
$\quad$ Tinggi & 2 & \\
\hline
\end{tabular}

Berdasarkan tabel 1 di atas, dapat dilihat bahwa sebagian besar orang tua berusia 41-60 tahun, berpendidikan perguruan tinggi, bekerja, berpendapatan di atas Rp 3.500.000, dan mengalami stress pengasuhan tingkat sedang. Analisis selanjutnya dilakukan untuk melihat korelasi usia orang tua dengan stress pengasuhan. Hasil analisis menunjukkan adanya hubungan yang signifikan antara usia dengan stress pengasuhan orang tua yang memiliki anak gangguan spektrum autisme $(r(31)=-.396, p<.05)$. Nilai koefisien korelasi negatif yang berarti semakin rendah usia orang tua maka akan semakin tinggi tingkat stres pengasuhan pada orang tua yang memiliki anak gangguan spektrum autisme.

Berdasarkan hasil analisis uji t ditemukan tidak perbedaan nilai rata-rata tingkat stres yang pengasuhan orang tua antara orang tua yang tidak bekerja dengan yang bekerja $(t(29)=.29, p>.05)$. Lebih lanjut uji anova dilakukan untuk melihat hubungan pendidikan dan pendapatan dengan stress pengasuhan yang dirasakan orang tua. Hasil uji anova menunjukkan adanya perbedaan nilai rata-rata tingkat stres pengasuhan antara orang tua yang memiliki tingkat pendidikan SD, SMP, SMA dan

Faizah Attamimi Nuha, Program Studi Kedokteran Fakultas Kedokteran Universitas Malahayati. Email: attamiminuha@gmail.com

Asri Mutiara Putri, Program Studi Psikologi Fakultas Kedokteran Universitas Malahayati. Email: asri@malahayati.ac.id

Nia Triswanti, Program Studi Kedokteran Fakultas Kedokteran Universitas Malahayati. Email: dr.niatriswanti82@gmail.com 


\section{HUBUNGAN ANTARA KARAKTERISTIK ORANG TUA DENGAN STRES PENGASUHAN PADA ORANG TUA ANAK GANGGUAN SPEKTRUM AUTISME}

perguruan tinggi $(F(3,28)=4.631, p<.05)$. Namun demikian uji anova terkait variable pendapatan, tidak menemukan adanya perbedaan nilai rata-rata tingkat stres pengasuhan antara pendapatan $<\mathrm{Rp}$. 1.500.000, Rp. 1.500.000-2.500.000, Rp. 2.500.000-3.500.000 dan > Rp. $3.500 .000(F(3,28)=2.572, p>$ $.05)$.

Hasil analisis regresi berganda dilalukan untuk mengetahui karakteristik orang tua yang paling dominan mempengaruhi stress pengasuhan. Berdasarkan analisis regresi berganda dengan metode enter yang dilakukan ditemukan bahwa usia, pendidikan, status pekerjaan, dan pendapatan menjelaskan jumlah yang signifikan dari varians stress pengasuhan $\left(F(3,28)=4.715, p<.05, R^{2}=.42, R^{2 \text { adjusted }}=.331\right)$. Lebih lanjut, hasil analisis terhadap pengaruh dari masing-masing variable ditemukan bahwa usia (Beta = 8.824, $\mathrm{t}(30)=-2.323, \mathrm{p}<.05)$ dan pendidikan $($ Beta $=-5.796, \mathrm{t}(30)=2.295, \mathrm{p}<.05)$ secara signifikan dapat memprediksi stress pengasuhan orang tua, sedangkan pekerjaan (Beta $=6.638, t(30)=1.667, p>$ .05) dan pendapatan (Beta $=-4.855, \mathrm{t}(30)=-1.974, \mathrm{p}>$.05) tidak signifikan memprediksi stress pengasuhan. Pada tabel 2 dapat dilihat bahwa nilai standar estimate menunjukkan arah hubungan negative yang artinya jika usia dan pendidikan mengalami peningkatan maka stres pengasuhan orang tua diprediksi akan menurun. Hasil analisis tersebut juga menunjukkan bahwa usia merupakan prediktor stress pengasuhan yang paling kuat dibandingkan pendidikan, pekerjaan, dan pendapatan.

\section{Tabel 2}

Kontribusi Variabel Karakteristik Orang Tua terhadap Stres Pengasuhan

\begin{tabular}{|c|c|c|c|}
\hline Model & B & Beta & $p$ \\
\hline Usia & -8.824 & -.372 & .028 \\
\hline Pekerjaan & 6.638 & .286 & .0108 \\
\hline Pendidikan & -5.796 & -.358 & .030 \\
\hline Pendapatan & -4.855 & -.334 & .059 \\
\hline
\end{tabular}

DISKUSI

Karakteristik Responden

Hasil penelitian menunjukkan bahwa distribusi frekuensi terbanyak berusia dewasa madya (41-60 tahun) sebanyak $61.3 \%$. Selama periode dewasa menengah, individu merasakan pengalaman dan penghargaan baik dalam karier maupun kehidupan personalnya. Menurut Hansson (2013) mengatakan bahwa pada usia antara 40-60 tahun orang tua telah banyak menyerap informasi seiring dengan kematangan usianya. Berdasarkan pendapat tersebut, pada

Faizah Attamimi Nuha, Program Studi Kedokteran Fakultas Kedokteran Universitas Malahayati. Email: attamiminuha@gmail.com

Asri Mutiara Putri, Program Studi Psikologi Fakultas Kedokteran Universitas Malahayati. Email: asri@malahayati.ac.id

Nia Triswanti, Program Studi Kedokteran Fakultas Kedokteran Universitas Malahayati. Email: dr.niatriswanti82@gmail.com 
Jurnal Psikologi Malahayati, Volume 2, No.2, September 2020: 36-47

\section{HUBUNGAN ANTARA KARAKTERISTIK ORANG TUA DENGAN STRES PENGASUHAN PADA ORANG TUA ANAK GANGGUAN SPEKTRUM AUTISME}

usia dewasa madya orang tua telah memiliki kematangan dan memiliki banyak pengalaman dalam mengasuh anak, sehingga mereka mampu mengasuh anak dengan baik.

Mayoritas status pekerjaan responden adalah bekerja sebesar $54.8 \%$. Jumlah jam kerja sangat berpengaruh terhadap intensitas pertemuan antara orang tua dan anak. Menurut Mehrota (dalam Kelrey, 2015) tingginya jumlah jam kerja mengurangi waktu kebersamaan dengan anak (quality time) antara orang tua dan anak yang dapat menimbulkan perasaan perpisahan (separation time) sehingga anak cenderung mencari perhatian di luar. Waktu kebersamaan dengan anak, tidak selalu menyangkut kuantitas namun juga mencangkup kualitas kebersamaan. Hal ini, harus ditunjang dengan mempertahankan kontak mata ketika berbicara dengan anak, memberikan sentuhan kasih sayang yang dapat menimbulkan perasaan hangat dan nyaman bagi anak (dalam Kelrey, 2015).

Mayoritas tingkat pendidikan responden adalah perguruan tinggi berjumlah $64.5 \%$. Orang tua dengan pendidikan yang semakin tinggi akan lebih memahami tumbuh kembang anak sesuai tahap perkembangannya (Muliana, 2014). Pendidikan yang tinggi juga mempengaruhi pola pikir orang tua dalam menghadapi suatu masalah termasuk kejadian autisme pada anak. Selain itu, pendidikan dan pengalaman orang tua dalam merawat anak akan mempengaruhi persiapan orang tua dalam menjalankan pengasuhan (Muliana, 2014). Menurut Brooks (dalam Muliana, 2014) tingkat pendidikan orang tua berperan penting dalam penerapan pola pengasuhan orang tua terhadap anak.

Mayoritas pendapatan responden lebih besar Rp. 3.500 .000 sebanyak $74.2 \%$ ). Hasil ini menunjukkan sebagain besar orang tua dalam penelitian ini berada dalam status sosial ekonomi menengah ke atas. Hal ini mengindikasikan sebagian besar orang tua dapat mengatasi permaslahan pengasuhan yang berkaitan dengan kebutuhan financial.

\section{Stres Pengasuhan}

Stres pengasuhan menurut Abidin (1992) adalah suatu kecemasan dan ketegangan yang melampaui batas secara khusus berhubungan dengan peran orang tua dan interaksi antara orang tua dengan anaknya. Stres pengasuhan dikarakteristikkan sebagai hasil dari ketidakseimbangan antara harapan orang tua terhadap dirinya sendiri maupun terhadap anaknya. Hasil penelitian menunjukkan bahwa distribusi frekuensi terbanyak pada tingkat stres pengasuhan sedang sebsar $74.2 \%$. Pada penelitian Phelps, McCammon, Wuensch \& Golden (2009) membuktikan bahwa orang tua yang memiliki anak cacat atau gangguan

Faizah Attamimi Nuha, Program Studi Kedokteran Fakultas Kedokteran Universitas Malahayati. Email: attamiminuha@gmail.com

Asri Mutiara Putri, Program Studi Psikologi Fakultas Kedokteran Universitas Malahayati. Email: asri@malahayati.ac.id

Nia Triswanti, Program Studi Kedokteran Fakultas Kedokteran Universitas Malahayati. Email: dr.niatriswanti82@gmail.com 
Jurnal Psikologi Malahayati, Volume 2, No.2, September 2020: 36-47

\section{HUBUNGAN ANTARA KARAKTERISTIK ORANG TUA DENGAN STRES PENGASUHAN PADA ORANG TUA ANAK GANGGUAN SPEKTRUM AUTISME}

diantaranya down syndrome, tourette syndrome, autisme dan ADHD, mengungkapkan bahwa yang memiliki tingkat stres pengasuhan tertinggi adalah orang tua dari anak dengan gangguan autisme. Oleh karena itu, berdasarkan hasil tingkatan stres pengasuhan orang tua yang memiliki anak gangguan spektrum autisme menunjukkan bahwa mayoritas responden tergolong masih dapat mengendalikan respon terhadap stressor dalam mengasuh anak dengan baik. Untuk menjadi orang tua diperlukan kesiapan khusus. Karakteristik psikologis orang tua menjadi yang terpenting karena mempengaruhi kemampuan mereka dalam memberikan pengasuhan yang berkualitas tinggi setelah anak lahir. Kesadaran pengasuhan juga merupakan modal penting untuk menciptakan ketahanan terhadap stres pengasuhan. Dengan memiliki kesadaran pengasuhan, maka pelaksanaan tugas pengasuhan anak yang melelahkan tidak terasa sebagai beban (Chairini, 2013).

\section{Usia dan Stres Pengasuhan}

Hasil analisis uji Korelasi Produt Moment Pearson menunjukkan bahwa terdapat hubungan negatif antara usia orang tua dengan stres pengasuhan orang tua yang memiliki anak gangguan spektrum autisme, artinya semakin rendah usia orang tua maka akan semakin tinggi tingkat stres pengasuhan pada orang tua yang memiliki anak gangguan spektrum autisme. Pada penelitian sebelumnya salah satu faktor yang berhubungan dengan rendahnya tingkat stres orang tua pada anak penyandang gangguan spektrum autisme adalah karakteristik usia orang tua (Putri, 2019). Rentang usia berada dalam tahap usia dewasa, dimana usia individu memulai tanggung jawab dan komitmennya serta dianggap lebih berpengalaman menetapkan keputusan, sehingga lebih mampu mengelola stressor dan mampu mengarahkan sumber stres ke arah yang positif (Putri, 2019).

\section{Pekerjaan dan Stres Pengasuhan}

Hasil analisis uji Independent Sampel Ttest menunjukkan bahwa tidak terdapat perbedaan nilai rata-rata tingkat stres pengasuhan orang tua antara orang tua yang tidak bekerja dengan yang bekerja. Hasil survey salah satu lembaga di Inggris, MIND tahun 2010 menyebutkan bahwa pekerjaan merupakan faktor utama penyebab stres (Chairini, 2013). Terkait dengan pengasuhan, penelitian yang dilakukan oleh Forgays (dalam Chairini, 2013) menunjukkan ibu yang bekerja memiliki skor yang lebih tinggi dibanding dengan ibu yang tidak bekerja dengan menggunakan kuesioner parenting stress index. Penelitian-penelitian yang dilakukan di luar negeri seperti Hidangmayum (2010) di Thailand dan Helkenn

Faizah Attamimi Nuha, Program Studi Kedokteran Fakultas Kedokteran Universitas Malahayati. Email: attamiminuha@gmail.com

Asri Mutiara Putri, Program Studi Psikologi Fakultas Kedokteran Universitas Malahayati. Email: asri@malahayati.ac.id

Nia Triswanti, Program Studi Kedokteran Fakultas Kedokteran Universitas Malahayati. Email: dr.niatriswanti82@gmail.com 
Jurnal Psikologi Malahayati, Volume 2, No.2, September 2020: 36-47

\section{HUBUNGAN ANTARA KARAKTERISTIK ORANG TUA DENGAN STRES PENGASUHAN PADA ORANG TUA ANAK GANGGUAN SPEKTRUM AUTISME}

(2007) di Canada menunjukkan adanya hubungan antara pekerjaan dengan stres pengasuhan, sementara bebrapa penelitian yang dilakukan di Indonesia seperti Indriyani (2008) menunjukkan tidak ada hubungan yang signifikan antara pekerjaan dengan stres pengasuhan (Chairini, 2013). Pada penelitian kali ini peneliti hanya membedakan jenis pekerjaan berdasarkan bekerja dan tidak bekerja dan didapatkan hasil tidak ada perbedaan antara orang tua yang bekerja maupun tidak bekerja sama-sama memiliki tingkat stres pengasuhan sedang yang diukur menggunakan kuesioner PSI (parenting stress index).

\section{Pendidikan dan Stres Pengasuhan}

Hasil analisis uji One Way Anova menunjukan bahwa terdapat perbedaan nilai rata-rata tingkat stres pengasuhan antara orang tua yang memiliki tingkat pendidikan SD, SMP, SMA dan perguruan tinggi. Perbedaan ini mungkin dikarenakan saat ini baik ibu dengan pendidikan rendah maupun tinggi dapat memperoleh pengetahuan mengenai pengasuhan anak dari berbagai sumber seperti televisi, media massa, radio maupun internet. Dengan kemudahan ini, ibu dapat mengetahui permasalahan anak, serta penanganannya dengan baik (Chairini, 2013). Selain itu faktor intelegensi dan faktor penyampaian informasi juga dapat mempengaruhi pengetahuan orang tua. Orang tua yang kurang membaca dan kurang mencari informasi akan mempunyai pengetahuan yang kurang dari pada orang tua yang sering membaca dan rajin mencari informasi maka pengetahuan lebih baik (Jeniu, Widodo, \& Widiani, 2017).

\section{Pendapatan dan Stres Pengasuhan}

Hasil analisis uji One Way Anova menunjukkan bahwa tidak terdapat perbedaan nilai rata-rata tingkat stres pengasuhan antara pendapatan < Rp. 1.500.000, Rp. 1.500.0002.500.000, Rp. 2.500.000-3.500.000 dan > Rp. 3.500.000. Status ekonomi sangat berpengaruh pada perkembangan hubungan orangtua dan anak. Penelitian yang dilakukan oleh Indriyani (2008) di Jakarta dan Hellken (2007) di Canada menyebutkan bahwa income yang diperoleh orang tua berpengaruh terhadap tingkat stres pengasuhan orangtua (Chairini, 2013). Orangtua dengan penghasilan rendah memiliki tingkat stres yang lebih tinggi dibandingkan dengan orang tua yang memiliki penghasilan tinggi. Hasil penelitian Chairini (2013) menemukan adanya hubungan negatif yang signifikan antara pendapatan dengan stres pengasuhan ibu dengan tingkat kekuatan hubungan moderat. Tingkat kepuasan orang tua terletak pada seberapa baik orang tua merasa mereka mampu memenuhi kebutuhan anak-anaknya. Orang tua yang kekurangan sumber daya untuk

Faizah Attamimi Nuha, Program Studi Kedokteran Fakultas Kedokteran Universitas Malahayati. Email: attamiminuha@gmail.com

Asri Mutiara Putri, Program Studi Psikologi Fakultas Kedokteran Universitas Malahayati. Email: asri@malahayati.ac.id

Nia Triswanti, Program Studi Kedokteran Fakultas Kedokteran Universitas Malahayati. Email: dr.niatriswanti82@gmail.com 
Jurnal Psikologi Malahayati, Volume 2, No.2, September 2020: 36-47

\section{HUBUNGAN ANTARA KARAKTERISTIK ORANG TUA DENGAN STRES PENGASUHAN PADA ORANG TUA ANAK GANGGUAN SPEKTRUM AUTISME}

merawat anak akan mengalami peningkatan stres dalam memenuhi tantangan kehidupan sehari-hari. Ketika mengalami kesulitan ekonomi, orangtua akan menjadi mudah marah, tertekan dan frustasi, serta tekanan psikologis mereka akan menurunkan kemampuan pengasuhan yang akan berpengaruh pada anak (Brooks, 2011 dalam Chairini, 2013).

\section{Karakteristik Orang Tua yang Paling} Dominan Memprediksi Stres Pengasuhan

Hasil uji regresi berganda didapatkan pengaruh yang signifikan antara karakteristik orang tua (usia, pendidikan, pekerjaan dan pendapatan) dengan stres pengasuhan orang tua yang memiliki anak gangguan spektrum autisme. Hasil penelitian ini didukung oleh penelitian Hidangmayum (2012) yang menjabarkan stres pengasuhan terdiri dari karakteristik anak dan karakteristik orang tua. Karakteristik orang tua terdiri dari usia orang tua, pendidikan orang tua, pekerjaan, dan penghasilan orang tua. Sedangkan menurut Mash dan Johnson (dalam Theule, 2011) menyebutkan bahwa karakteristik anak dan faktor lingkungan adalah faktor-faktor yang mempengaruhi parenting stress (stres pengasuhan). Dimana pengaruh anak dan lingkungan dimediasi oleh karakteristik orang tua.

Lebih lanjut, hasil penelitian menunjukkan bahwa variabel usia dan pendidikan memiliki pengaruh yang signifikan terhadap stres pengasuhan, dimana usia menjadi faktor yang paling dominan. Hasil ini didukung oleh penelitian sebelumnya, salah satu faktor yang berhubungan dengan rendahnya tingkat stres orang tua pada anak penyandang gangguan spektrum autisme adalah karakteristik usia orang tua (Putri, 2019). Rentang usia orang tua berada dalam tahap usia dewasa, dimana usia individu memulai tanggung jawab dan komitmennya serta dianggap lebih berpengalaman menetapkan keputusan, sehingga lebih mampu mengelola stressor dan mampu mengarahkan sumber stres ke arah yang positif (Supriati \& Selvitriana, 2018).

Dan dari penelitian Rahmah dan Marini dalam Muliana, 2014) menjelaskan bahwa faktor pendidikan orang tua, kelas sosial ekonomi, konsep tentang peran orang tua, kepribadian orang tua, kepribadian anak, dan usia anak memberikan pengaruh pada pola asuh ibu suku Batak dengan anak laki-laki autistik. Pendidikan yang tinggi mempengaruhi pola pikir orang tua dalam menghadapi suatu masalah termasuk kejadian autisme pada anak. Selain itu, pendidikan dan pengalaman orang tua dalam merawat anak akan mempengaruhi persiapan orang tua dalam menjalankan pengasuhan (Muliana, 2014). Hal ini sejalan dengan pendapat Brooks (dalam Muliana, 2014) bahwa tingkat pendidikan orang tua berperan penting

Faizah Attamimi Nuha, Program Studi Kedokteran Fakultas Kedokteran Universitas Malahayati. Email: attamiminuha@gmail.com

Asri Mutiara Putri, Program Studi Psikologi Fakultas Kedokteran Universitas Malahayati. Email: asri@malahayati.ac.id

Nia Triswanti, Program Studi Kedokteran Fakultas Kedokteran Universitas Malahayati. Email: dr.niatriswanti82@gmail.com 


\section{HUBUNGAN ANTARA KARAKTERISTIK ORANG TUA DENGAN STRES PENGASUHAN PADA ORANG TUA ANAK GANGGUAN SPEKTRUM AUTISME}

dalam penerapan pola pengasuhan orang tua terhadap anak.

\section{Keterbatasan Penelitian}

Pada penelitian ini masih terdapat banyak kekurangan yaitu beberapa responden tidak bersedia mengisi kuesioner, kesibukan responden membuat peneliti kesulitan dalam mendapatkan responden, beberapa responden mengetahui dirinya sedang diteliti, sehingga dapat mempengaruhi jawaban dari responden dan sulitnya bertemu dengan responden dikarenakan ditengah penelitian semua SLB mengikuti kebijakan pemerintah untuk belajar dirumah dan Social Distancing selama dalam pandemi Covid-19.

\section{SIMPULAN DAN SARAN}

Berdasarkan hasil penelitian, dapat disimpulkan bahwa terdapat hubungan antara karakteristik orang tua (usia, pekerjaan, pendidikan dan pendapatan) dengan stres pengasuhan orang tua yang memiliki anak gangguan spektrum autisme di SLB se-Bandar Lampung. Usia dan pendidikan ditemukan sebagai faktor yang paling dominan dalam memprediksi stress pengasuhan. Untuk penelitian selanjutnya sebaiknya memiliki cara yang efektif untuk pengumpulan responden, jumlah responden sebaiknya diperbanyak agar dapat mencerminkan kondisi yang sesungguhnya. Selain itu, peneliti selanjutnya membedakan tingkat keparahan dan symptom yang ditunjukkan anak autis, karena menurut Berkell (1992) tingkat keparahan anak autis mempengaruhi penyesuaian diri orang tua. Semakin tinggi tingkat keparahan anak autis akan semakin tinggi tingkat stres yang dirasakan orang tua.

\section{DAFTAR PUSTAKA}

Abidin, R. R. (1992). The determinants of parenting behavior. Journal of clinical child psychology, 21(4), 407-412.

Chairini, N. (2013). Faktor-faktor yang berhubungan dengan stres pengasuhan pada ibu dengan anak usia prasekolah di Posyandu Kemiri Muka.

Fido, A., \& Al Saad, S. (2013). Psychological effects of parenting children with autism prospective study in Kuwait. Open journal of psychiatry, 3(02), 5 .

Gupta, V. B., Mehrotra, P., \& Mehrotra, N. (2012). Parental stress in raising a child with disabilities in India. Disability, CBR \& Inclusive Development, 23(2), 41-52.

Hansson $P$, Rounnlund M, Juslin P \& Nilsson L, 2013. Adult age differences in the realism of confidence judgmens: Overconfidence, format dependence and cognitive predictors. Psychology and Aging. 23 (3), 531-544.

Faizah Attamimi Nuha, Program Studi Kedokteran Fakultas Kedokteran Universitas Malahayati. Email: attamiminuha@gmail.com

Asri Mutiara Putri, Program Studi Psikologi Fakultas Kedokteran Universitas Malahayati. Email: asri@malahayati.ac.id

Nia Triswanti, Program Studi Kedokteran Fakultas Kedokteran Universitas Malahayati. Email: dr.niatriswanti82@gmail.com 


\section{HUBUNGAN ANTARA KARAKTERISTIK ORANG TUA DENGAN STRES PENGASUHAN PADA ORANG TUA ANAK GANGGUAN SPEKTRUM AUTISME}

Hidangmayum, N., \& Khadi, P. B. (2012). Parenting stress of normal and mentally challenged children. Karnataka Journal of Agricultural Sciences, 25(2).. Naskah Publikasi Thesis University of Agricultur Science.

Indriyani, I. (2008). Pengaruh Kepuasan Pernikahan terhadap Parenting Stres: studi pada ibu dengan anak usia 2-5 tahun. Skripsi. Fakultas Psikologi. Universitas Islam Negeri Syarif Hidayatullah. Jakarta.

Jeniu, E., Widodo, D., \& Widiani, E. (2017). Hubungan Pengetahuan tentang Autisme dengan Tingkat Kecemasan Orang tua yang memiliki Anak Autisme di Sekolah Luar Biasa Bhakti Luhur Malang. Nursing News: Jurnal IImiah Keperawatan, 2(7).

Judarwanto. (2015). Intervensi diet pada penderita autisme. Diperoleh tanggal 11 Januari 2018 dari: https:/jurnalpediatri.com/2015/03/24/int ervensi-diet-pada-penderita-autisme/

Kelrey, D. S. R. (2015). Hubungan Karakteristik Orang Tua Dengan Pengetahuan Orang Tua Tentang Kekerasan Seksual Pada Anak Usia Prasekolah (3-5 Tahun) Di Kelurahan Grogol Selatan Kebayoran Lama Jakarta Selatan.

Maysa, P., \& Khairiyah, U. (2019). Hardiness dan Stres Pengasuhan pada lbu dengan Anak Berkebutuhan Khusus. Jurnal RAP (Riset Aktual Psikologi Universitas Negeri Padang), 10(1), hal 88-101.
Muliana, dkk. 2014. Pengaruh Karakteristik Orang Tua Terhadap Jenis Pola Asuh Dalam Merawat Anak Penyandang Autisme. Jakart: Jurnal FIK UI, hal, 4

Pamungkas, A. P. (2015). Pelatihan keterampilan pengasuhan autis untuk menurunkan stres pengasuhan pada ibu dengan anak autis. Empathy, 3(1).

Phelps, K. W., McCammon, S. L., Wuensch, K. L., \& Golden, J. A. (2009). Enrichment, stress, and growth from parenting an individual with an autism spectrum disorder. Journal of Intellectual and Developmental Disability, 34(2), 133141.

Putri, A. M., Pramesti, W., \& Hapsari, R. D. (2019). Stres pada orang tua yang memiliki anak dengan gangguan spektrum autisme. Jurnal psikologi malahayati, 1(1).

Ramadhany, S., Larasati, T.A., Soleha, T.U. (2017). Faktor-faktor ang berhubungan dengan tingkat stres pengasuhan pada ibu ang memiliki anak tunagrahita di SLB Dharma Bakti Dharma Pertiwi. J Agromed UNILA, 4(2), 287-292.

Soendari, T. (2016). Penyandang Autis Dalam Isu Global (Sebuah Pengantar menuju Model Konseling yang Efektif di Sekolah). JASSI ANAKKU, 12(1), 8796.

Suryati, S., \& Rahmawati, R. (2017). Pengaruh Terapi Bermain Terhadap Interaksi Sosial Anak Autis Di Sdlb Prof. Dr. Sri Soedewi Masjchun Sofwan, Sh Jambi Tahun 2014. Jurnal IImiah Universitas Batanghari Jambi, 16(1), 142-147.

Faizah Attamimi Nuha, Program Studi Kedokteran Fakultas Kedokteran Universitas Malahayati. Email: attamiminuha@gmail.com

Asri Mutiara Putri, Program Studi Psikologi Fakultas Kedokteran Universitas Malahayati. Email: asri@malahayati.ac.id

Nia Triswanti, Program Studi Kedokteran Fakultas Kedokteran Universitas Malahayati. Email: dr.niatriswanti82@gmail.com 
HUBUNGAN ANTARA KARAKTERISTIK ORANG TUA DENGAN STRES PENGASUHAN PADA ORANG TUA ANAK GANGGUAN SPEKTRUM AUTISME

Supriati, L., \& Selvitriana, D. R. (2018). The Relationship of Family Support with SelfEsteem Level in People Living with HIVIAIDS (PLWHA) in Sadar Hati Foundation Malang. Journal Nursing Care and Biomolecular, 3(1), 6-14..

Theule, J., Wiener, J., Rogers, M. A., \& Marton, I. (2011). Predicting parenting stress in families of children with ADHD: Parent and contextual factors. Journal of Child and Family Studies, 20(5), 640-647.

Faizah Attamimi Nuha, Program Studi Kedokteran Fakultas Kedokteran Universitas Malahayati. Email: attamiminuha@gmail.com

Asri Mutiara Putri, Program Studi Psikologi Fakultas Kedokteran Universitas Malahayati. Email: asri@malahayati.ac.id

Nia Triswanti, Program Studi Kedokteran Fakultas Kedokteran Universitas Malahayati. Email: dr.niatriswanti82@gmail.com 